\title{
WHO DEFINES URBAN REGENERATION? COMPARATIVE ANALYSIS OF MEDIUM-SIZED CITIES IN POLAND AND RUSSIA
}

\author{
Przemysław Ciesiółka ${ }^{1}$ (D) - Maria Gunko² (D) - Galina Pivovar ${ }^{3}$ \\ ${ }^{1}$ Faculty of Human Geography and Planning \\ Adam Mickiewicz University in Poznań \\ Krygowskiego 10, 61-680 Poznań: Poland \\ e-mail: przemko@amu.edu.pl (corresponding author) \\ ${ }^{2}$ Institute of Geography \\ Russian Academy of Sciences \\ Staromonetny pereulok 29, 119017 Moscow: Russia \\ e-mail: msgunko@igras.ru \\ ${ }^{3}$ 'Skolkovo' Moscow School of Management \\ Novaya ulitsa 100, 143025 Skolkovo Odintsovsky rayon, Moscow oblast: Russia \\ e-mail: gpivovar@skolkovo.ru
}

\begin{abstract}
The aim of the current study was to identify the main actors (leaders) involved in transformations of mediumsized cities in Poland and Russia that share similar legacies but took different development paths after the collapse of state socialism. These transformations are discussed using the framework of urban regeneration and are based on empirical data from two cities - Kolomna (Russia) and Kalisz (Poland). The data were obtained through expert interviews, as well as nonparticipant observation in the two cities. Though the process of urban regeneration shows similarities, the process leaders are different.
\end{abstract}

\section{Key words}

urban transformations $\cdot$ urban change $\cdot$ urban regeneration $\bullet$ urban planning - medium-sized cities - Eastern Europe - Poland • Russia

\section{Introduction}

Narratives of urban change such as renewal, revitalization, recovery, and regeneration have attracted growing attention in urban studies over the recent years (e.g. Couch,
Sykes, \& Börstinghaus, 2011; Dalla Longa, 2011; Ryan, 2012; Watcher \& Zeuli, 2014; Carter, 2016; Van Agtmael \& Bakker, 2016; Doucet, 2017; Roberts, Sykes, \& Granger, 2017; Kaczmarek, 2019). The 're-' prefix indicates repetitiveness (Cambridge Dictionary) 
- a new interpretation or (re)creation of something that already exists or existed in the past. Generally, re-narratives refer to the changes taking place in degraded urban areas, rather than to the changing development path of a city as a whole (Roberts, 2016: 19-20). However, the scope of use of re-terms remain ambigous.

Drawing attention to 'successful' cases and 'best' practices, re-narratives have been predominantly informed by the experiences of large cities that enjoy positive externalities of the agglomeration effect, support of the national government, and receive a large share of private investments. At the same time, small and medium-sized cities (SMSC) as well as non-core regions are discussed to a lesser extent (Stryjakiewicz et al. 2018). The reasons behind such selective analysis of urban experiences include, on the one hand, a 'fascination' with large cities, which showcase global processes, and, on the other hand, the ontological complexity of SMSC, which are more sensitive to differences in cultural and institutional contexts, and the simple lack of comparable data (Atkinson, Servillo, \& Hamdouch, 2016).

In European countries, over half of all urban dwellers live in SMSCs with a population below 200 thousand people (CEC, 2011); such cities play an important role in terms of employment and services provision (ESPON, 2014). This calls for closer examination of the challenges that SMSCs face - depopulation, economic restructuring and associated unemployment, budget austerity, declining livability withdrawal of public services, and dependency on higher levels of decision-making (Hamdouch, Nyseth, Demazière, Førde, Serrano, \& Aarsæther, 2017) - and the opportunities that they have to overcome them.

Our contribution seeks to shed light on the transformations taking place in urban areas of Eastern Europe with empirical evidence from Poland and Russia. Here, SMSCs are confronted with many of the above-listed challenges caused by the shortcomings of urban planning and policies during state socialism, as well as the currently increasing socio-economic and spatial inequality (Lang, Henn, Sgibnev, \& Ehrlich, 2015; Śleszyński, 2017; Zupan \& Gunko, 2020). The focus is on medium-sized cities, which remain largely understudied, since scholars tend to focus either on large or (less frequently) small cities. Medium-sized cities are 'in-between' places that share qualities of both large and small cities; a precise definition of them does not exist. However, as noted by Gómez, González, and Navarro (2019: 4) 'from a quantitative perspective, a pragmatic definition can be established, although it will always be incomplete'. In Europe, based on various estimates, cities with a population size ranging between 20 and 500 thousand are considered to be medium-sized (European Union, 1994; Cheshire, Hay, Carbonaro, \& Bevan, 1988; Henderson, 1997; Kunzmann, 2010). In the Russian tradition, 'medium-sized' refers to cities with populations between 50 and 100 thousand people (Lappo, 1997; Set of Rules, 2011). In the current study we use a trade-off between these population margins to delimit medium-sized cities: between 50 and 200 thousand people. With minor exceptions, medium-sized cities, like small cities, have not been in the focus of national policies. But as they have larger populations and economy size, the neglect of their issues has resulted in highly uneven intraurban development with vast areas of degradation affecting a significant population.

Against the above background we use the framework of urban regeneration and draw attention to the positive changes taking place in selected Polish and Russian medium-sized cities. The aim of the study is to identify the main actors (leaders) of change, and discuss the scope of their activities, the relationships between them, their principles of cooperation, and emerging conflicts. This permits a verification of the prospects for partnerships in urban regeneration, and, more generally, overall urban development. The empirical evidence is drawn from Kolomna (Russia) and Kalisz (Poland). The structure of the paper is as follows. Section 2 introduces 
the theoretical framework. Section 3 is devoted to the methodological approach. Section 4 explores the cases to reveal the relationship between actors and processes, comparing the experiences of the two cities. The final sections 5 and 6 provide an overview of the issues at hand.

\section{Theoretical framework}

In the current paper urban regeneration is understood, rephrasing Roberts (2016: 18), as a comprehensive process which leads to lasting improvements of physical, social, economic, and environmental conditions of degraded urban areas. In this respect, we distinguish between urban regeneration and urban renewal: the latter is viewed as a merely physical change focused on urban design with limited capacity to address comprehensive issues (Granger, 2010). Moreover, it is important to make a distinction between urban regeneration and gentrification. As Granger (2010; 2016) notes, while gentrification often brings positive change to an area through reinvestment, it remains a negative spatial expression of capitalism. Unlike regeneration, gentrification precludes lasting change for all residents and marginalizes some social groups (Lees, Slater, \& Wyley, 2008), representing 'deliberate, often revanchist, attempts to commercialize cities' (Granger, 2010: 11).

\section{Actors and leaders}

\section{of urban regeneration}

The transformations in urban quarters and their spatial, functional, and social structures are due to a complex set of reasons, circumstances, and courses of events (Kaczmarek, 2019) requiring collaboration between a wide range of actors (e.g. Bentley, Pugalis, \& Shutt, 2017; Sotarauta, Beer, \& Gibney, 2017; Beer, Ayres, Clower, Faller, Sancino, \& Sotarauta, 2019). The success of such a change is largely dependent on whether a shared vision and common goals exist among those involved (Roberts \& Sykes, 2000). According to Hall (2006) the national, subnational (regional), and local governments, as well as the private sector, voluntary sector, and the local community, are those who may take part in the process of urban change. However, there is no precise list of actors because 'leadership is a socially constructed and geographically contingent phenomena' (Kinossian, 2019: 64). The dominance of certain actors determines the course of urban change, its character and, consequently, its final effects. Rodriguez-Pose (2013) suggests that leadership may be the missing factor in efforts to understand why some places succeed and others fail. Of course, the emergence of leadership and the way it functions depends largely on socio-economic, cultural, and institutional conditions of a given place (Collinge, Gibney, \& Mabey, 2010; Beer, 2014).

\section{Partnership model}

Over the years, we have witnessed shifts in the roles that various actors play in urban regeneration taking place in Western Europe. Stohr (1989) and Lichfield (1992) underline that since the 1980s the partnership model has become predominant. This is the effect of abandoning the idea that the central government should be the exclusive provider of resources required to support policy interventions (Roberts, 2016). As Carter (2000) emphasizes there are a number of reasons behind the move towards multiagency partnerships in regeneration. Among them are, first, the current political agenda in European countries, which is forcing the pace in this area; second, the multidimensional and complex nature of urban problems, which requires integrated, coordinated, and multifaceted strategies involving a wide range of actors; third, the fragmentation of duties and organizations involved in the development of urban areas; fourth, the local community's expectations with respect to defining and implementing the most appropriate responses to the challenges their locality is facing. A partnership approach should be adopted especially when projects bring together local politicians, residents, and civil society groups (Couch, Sykes, \& Börstinghaus, 
2011). As with the list of actors, there is no single form of partnership (e.g. Carley, 2000; Carter, 2000). Mackintosh (1992) and Carter (2000) list the following main models of partnership in regeneration scenarios: (1) the synergy model, which assumes that actors work together because by sharing their knowledge, resources, approaches, and operational cultures they will be able to achieve more, (2) the budget enlargement model, which is based on the knowledge that by working together the partners will gain access to additional funds, (3) the transformational model, which suggests that it is beneficial for partners to expose themselves to each other's assumptions and working methods.

\section{Urban change and regeneration in Central and Eastern Europe}

Central and Eastern Europe (CEE) has a shorter tradition in the field of urban regeneration than Western Europe. Despite this, the need for the transformation of degraded urban areas is just as essential here. During state socialism the inner and central parts of noncapital cities often faced decline in economic, physical, and social terms. New political and economic conditions after the collapse of state socialism in the 1990s seemed to create opportunities for promoting positive changes in previously neglected urban areas and neighborhoods. Local autonomy has been re-established and political institutions have been rapidly evolving in order to manage these changes (Scott \& Kühn, 2012). However, as Temelova (2009) points out, the real power and scope of action that public authorities have in guiding urban transformation remains much weaker in CEE countries than in Western Europe. Though budget austerity and restrictions imposed by private land ownership are common issues in many European countries, protracted bargaining processes and lack of experience and expertise impose additional challenges in the CEE context (Badyna \& Golubchikov, 2005). Numerous examples prove that the 'Western' approach towards the development of urban areas does not always work in CEE countries (e.g. Feldman, 2000; Foldi, 2006; Temelova, 2009; Kaczmarek \& Marcińczak, 2013; Inizan \& Coudroy de Lille, 2019). Feldman (2000) argues that this results also from the lack of partnership and cooperation among actors coupled with the continued pivotal role of the central government in urban planning. There is continuing difficulty with involving local communities due to lack of initiative and leadership on the one hand, and the manipulative nature of participation procedures on the other (Gustafsson \& Elander, 2015; Gunko \& Pivovar, 2018). As a result, private investors are often much more important in regeneration, which leads to regeneration turning into de facto gentrification (Sykora, 2005) with subsequent loss of social diversity in the affected area due to rent increases and changes in housing tenure (Granger, 2010, 2016).

Despite the growing interest in urban regeneration and its main actors in CEE countries (see e.g. Frantal, Kunc, Novakova, Klusaček, Martinat, \& Osman, 2013; Krzysztofik, Kantor-Pietraga, \& Spórna, 2013; Alexandrescu, Martinat, Klusácek, \& Bartke, 2014; Lux \& Horvath, 2018; Doğan, 2019; Gorzelak, 2019), as in other parts of the world the spotlight remains on large cities. The current contribution, on the contrary, emphasizes the experience of medium-sized cities, which is less discussed in the literature. We analyze actors of change and potential for partnership, as well as taking into account the factors specific to Poland and Russia that determine the occurrence (or absence) of leadership in the process of regeneration.

\section{Methodological approach}

A mixed-method approach was used in the study (Johnson \& Onwuegbuzie, 2004). It involved desk research, including a qualitative content analysis of legislation and policy documents. This allowed the study of urban regeneration strategies implemented on the national, regional, and local levels (Tab. 1) in Russia and Poland with a focus on items 
Table 1. Information about the case study cities

\begin{tabular}{|l|c|c|}
\hline & Kolomna & Kalisz \\
\hline Population (2017) & 144125 & 100975 \\
$\begin{array}{l}\text { Change in the number of residents in the years } \\
\text { 1999-2017 }\end{array}$ & $-4.8 \%$ & $-7.5 \%$ \\
First regeneration initiatives (year): & 2008 & 2008 \\
$\begin{array}{l}\text { Current document regulating regeneration } \\
\text { (year of preparation) }\end{array}$ & $\begin{array}{c}\text { Municipal program 'Formation } \\
\text { of a comfortable contemporary } \\
\text { urban environment' (2017) }\end{array}$ & $\begin{array}{c}\text { Municipal regeneration program } \\
\text { (2018) }\end{array}$ \\
Type of regeneration area & City centre & City centre \\
\hline
\end{tabular}

Source: own compilation, population data provided by Rosstat (Russia) and Statistics Poland.

such as urban regeneration goals, legal regulations, areas subject to regeneration, and the main types of regeneration projects. Furthermore, we incorporated case study research with expert interviews and nonparticipant observation in two cities: Kolomna (Russia) and Kalisz (Poland). The choice of cities was based on a comparative case study selection approach (Seawright \& Gerring, 2008) with the following determining factors: similarities in the number of inhabitants and its changes in recent years, the beginning of regeneration activities and the type of area subject to change (Tab.1).

The guide for the semi-structured interviews touched on three groups of issues: (1) the role of national, regional, and local programs in the regeneration, (2) the evaluation of local, including bottom-up, initiatives that promote regeneration, (3) the role of different actors in the regeneration, their motivations and resources, as well as actor networks and partnerships if present. The interviews were conducted with 11 (in Russia) and 7 (in Poland) individuals from different groups of actors: local and regional authorities, entrepreneurs and cultural sector employees, representatives of NGOs. Respondents were selected using a snowballing technique based on their importance for regeneration activities in the given city (according to the impressions of previously interviewed actors). Interviews were conducted face to face (in Russia and Poland) and via e-mail (in Poland).

\section{Results: the role of various actors in urban regeneration}

\section{The case of Poland}

National regulations

In the 1990s and the early 2000s, urban regeneration activities in Poland were spontaneous and somewhat chaotic, since a general vision of urban development was lacking. 'Regeneration' in this period implied only the physical change of degraded areas, and thus was actually renewal. Accession to the European Union in 2004 played a key role in changing this trend. Cities and municipalities received organizational and financial support, which in subsequent years resulted in systemic changes at the national level. Currently, urban regeneration is an important element of the state's policy as reflected in the national Strategy for Responsible Development and the National Regeneration Plan (Ciesiółka, 2018). Furthermore, the Regeneration Act adopted in 2015 created a solid legislative framework for the transformation of degraded urban areas. Since 2015, emphasis has been placed on the social aspects of change, turning renewal into regeneration. The basic source of financing for urban regeneration in Poland is the European Union funds directed in the form of subsidies to local authorities, as well as in the form of low-interest loans for entrepreneurs (JESSICA Initiative). The total value of regeneration projects planned until 2023 
in Poland exceeds 11 billion euros (Jarczewski \& Kułaczkowska, 2019).

The National Program 'Package for medium-sized cities' provides funds to support the development of medium-sized cities that are losing their socio-economic functions and plays an important role in both their socioeconomic and their physical transformation. Even though the National Regeneration Plan and the National Program 'Package for medium-sized cities' were adopted at the central level, regeneration programs prepared at the local level are of key importance. At the end of 2017, over $53 \%$ of municipalities (communes) in Poland had such documents (Statistical data on ..., 2018). The rules for developing, implementing, and monitoring the course of regeneration programs are standardized. At the local level, they are coordinated by the local authorities, which prepare regeneration programs and decide on the involvement of other actors in regeneration activities. This may be done for example through Regeneration Committees (hereafter - Committees): social advisory bodies appointed by the local authorities. They are mandatory if local authorities want to use the additional legal and organizational instruments supporting regeneration that are listed in the Regeneration Act, i.e. investment reliefs in the area under regeneration, or additional sources of funding. At the end of 2017, Committees operated in approx. 51\% of municipalities that had adopted regeneration programs. While de jure Poland promotes conducting regeneration in a participatory manner, de facto Committees remain the core tools.

\section{The case of Kalisz}

Kalisz is located in the southern part of the Wielkopolskie Voivodeship, around $100 \mathrm{~km}$ from large urban centers - Poznań, Łódź, and Wrocław. Kalisz is thought to be one of the oldest urban centers in Poland, with first records of a settlement dating back to the beginning of our era; however, it received city rights much later, in the 13th century. A city with a rich history, and theaters, museums, art galleries, and a concert hall, Kalisz is an important cultural center that attracts tourists on a daily basis and during festivals (e.g. Jazz Pianists Festival, International Festival of Street Art Activities, Fingerstyle Feeling Festival). However, it seems that it has yet to fully realize its historical and cultural potential, which was emphasized during the interviews held in the course of this study. Concurrently to the cultural component, the city is also a center for industry, hosting aviation, textile, clothing, and food processing sectors; however, services are the dominant sphere of employment.

Over the recent decades Kalisz has been losing population (about $7 \%$ in the last 20 years) and at the end of 2018 it had about 101 thousand residents. The decisive factor for depopulation is the city's peripheral location, which causes out-migration, primarily of young people who move to larger centers (Statistics Poland, 2018). In parallel to general out-migration, suburbanization is also progressing. As a result, the city's central quarters are confronted with social and spatial degradation. Poverty is a big issue, along with a low level of entrepreneurship, air pollution, and heavy traffic congestion.

The first initiatives in the field of regeneration in Kalisz were undertaken before 2010 and targeted the city center and post-industrial areas. However, due to lack of funding, these activities were discontinued. Regeneration saw a new beginning in 2016, following the adoption of the Municipal Regeneration Program (hereafter - Regeneration Program) and supported by EU funds. The goals of the Regeneration Program included reducing the scale of social problems, strengthening economic potential, increasing the quality of public spaces, as well as improving the technical condition of buildings, housing, and transport infrastructure. The Program covers dozens of activities of a diverse nature in the city center, such as modernization of the Old Market and the city park, redesign of the transport system, systematic replacement of traditional heating boilers, as well as creation of social integration centers (e.g. Community Center, the Non-governmental Organizations Center, and Cultural Center). Some of these activities 
have already been implemented (construction of the Neighborly House meeting center and renovation of residential buildings located in the area of the Old Market) while the rest are in progress. It is thus still too early to carry out a final evaluation of regeneration activities in Kalisz, but the changes have undoubtedly met a positive social response, as evidenced by interview respondents.

To manage the Regeneration Program, a separate unit was established within city office structures: the Regeneration Office. It played a key role in the process of diagnosing, programming, and implementing regeneration activities; it was also responsible for informing the public about the progress of regeneration activities based on a monitoring and evaluation system it created. Another aspect of its work was to activate other actors to join in regeneration, through events encouraging residents to use trade and services in the city center, training workshops for residents and entrepreneurs, as well as subsidies for property owners for renovation of residential buildings.

When work on the new Regeneration Program began, the mayor of Kalisz appointed a Regeneration Committee, which included residents of the areas subject to regeneration activities, entrepreneurs, representatives of non-governmental organizations, property managers, as well as representatives of national authorities. There was an obvious attempt to build a partnership based on a synergy model (see Mackintosh, 1992). However, no leader who played a significant role in the regeneration of Kalisz emerged from this body; the employees of the Regeneration Office, who were also part of the Regeneration Committee, were the most active. Meanwhile, ordinary citizens, entrepreneurs, and NGO representatives seem reluctant to take matters into their own hands and invest time and resources, even in their immediate surroundings - apartment buildings, courtyards, streets. Some exception to this is noted in several entrepreneurs who carried out activities in the city center - contractors of the Calisia One hotel and office complex (on the premises of the former 'Calisia' piano factory). The resulting change in the cityscape undoubtedly increased the prestige of the area. However, it did little to improve the lives of the areas' residents; in this respect, to some extent these activities resemble gentrification rather than regeneration.

Summing up, in Kalisz the core actors of regeneration are the representatives of the local authorities. They initiated the changes in the city center and were responsible for both the development of the Regeneration Program and the implementation of regeneration activities. EU funds allocated to them were the main source of financing. Attempts are being made to involve other actors in regeneration, in particular local residents, representatives of non-governmental organizations, and entrepreneurs. Their role is still marginal, however. As a result, there is no lasting partnership between various actors.

\section{The case of Russia \\ National regulations}

Unlike in Poland, there is no comprehensive national policy towards regeneration of urban areas in Russia. Its closest counterparts include the state Priority Program 'Integrated development of single-industry towns for the period 2016-2025' adopted in 2016 (Ministry for Economic Development of the Russian Federation 2016) and the state Priority Project 'Formation of a comfortable urban environment' adopted in 2017 (Ministry for Construction, Housing, and Communal Services of the Russian Federation 2017). The core aim of the Priority Program, which targets around $30 \%$ of Russian cities: those are officially considered to be single-industry towns, is to balance their budgets and address other most pressing issues in order to prevent the social tensions and mass protests that were common in some of them at the end of the 2000s (TASS, 2013). However, in 2019, as a result of widespread criticism, the Program was abolished before the funding period ended. The discussion of a new Program for singleindustry towns is still ongoing. Unlike the Priority Program, the Priority Project covers all 
Russian cities, aiming to improve the physical features of their cityscapes. Under the Priority Project, each urban municipality adopts its own eponymous municipal program, partially subsidized by the state, where it lists the types of improvements and the areas that are to undergo them. The funding and organizational schemes of the Priority Project focus primarily on courtyards within housing estates and on public spaces, involving the implementation of highly visible and easily graspable, but insubstantial and one-off improvements that do not help with insufficient and unbalanced provision of infrastructure and growing socio-spatial inequalities (Zupan \& Gunko, 2020). Since social and economic problems, as well as more comprehensive issues of the living environment, e.g. housing, roads, and infrastructure, are not included in the Priority Project, it cannot be regarded as a fullyfledged regeneration scheme. In the lack of a proper national policy, other actors emerge on the arena with various interests, views of what is good or bad, and capacity to promote change. Thus, the process of change in Russian cities remains ad hoc, varying from one place to another.

\section{The case of Kolomna}

Kolomna is one of the second-tier cities of the Moscow city-region with a population of 144 thousand people. It is located little over $100 \mathrm{~km}$ from Moscow, but the time of travel is over 1.5 hours and may lengthen due to traffic jams. This makes the city a center of employment and services for its own population and that of neighboring districts rather than a commuting suburb of the national capital. Kolomna dates back to the beginning of the 12th century and has the corresponding historical and cultural heritage which attracts tourists. At the same time according to statistical data it is an industrial city, with $83 \%$ of its production being related to machinery (Kolomna Plant, Kolomna Heavy Machine Tool Plant, and smaller enterprises) and the military-industrial complex (Machine Building Design Bureau). However, employment in the manufacturing industry does not exceed a quarter of the total economically active population.

Two factors are the most important for understanding urban change in Kolomna. First, its relative proximity to Moscow, which provided the city with an influx of seasonal population and weekend tourists. Second, the dense historical environment of the city center. The main landmarks include Kolomenskiy Kremlin, thirteen churches (the oldest Uspenskay church dating back to the 16th century), and the fortress gates (Pyatnitskie vorota). There are over four hundred historical landmarks in the city, seventy of which have the official status 'Cultural Heritage of Federal Importance'. However, the potential of the city center's historical and cultural environment was not realized until the end of the 2000 s due to the lack of tourist infrastructure and areas of degradation, mainly within residential quarters.

The starting point for the change was the construction of a new ice-skating arena to host the Icehouse Festival (Festival Ledyanoy Dom) in 2008, initiated by the regional and local authorities as a supporting event for the European speed skating championship. The overall idea of the festival was to attract new investments to the city by promoting and rebranding its intangible and tangible heritage. This idea was quickly picked up by creative entrepreneurs who then became the leaders of regeneration. Thus, at the core of Kolomna's regeneration lies its heritage, namely traditional crafts and products. The most important is Kolomenskay pastila (traditional Russian apple dessert), which was prepared by a pair of entrepreneurs in 2008 for the guests of the Icehouse Festival and became an immediate success. The next, 'Antonov Apples Festival' ('Festival Antonovskie yablo$\left.k i^{\prime}\right)$, became a forerunner of a massive change in Kolomna's city center - its transformation into a place of high historical and cultural value and intellectual leisure activities. The name of the festival was inspired by the eponymous tale by Russian writer Ivan Bunin, Nobel Laureate in Literature, simultaneously allowing associations with pastila (which is made 
of apples) - the new symbol of the city, and with the city's cultural heritage. In 2018, a Historical Production Parade took place alongside the 'Antonov Apples festival'. The event was aimed at promoting the historical industries of Kolomna, drawing attention to alternative approaches to industrial culture.

The cultural festivals, the need to promote Kolomenskay pastila, and the creative aspirations of entrepreneurs resulted in the opening of the first private museum: 'Museum of disappeared flavors' ('Muzey ischeznuvshego vkusa'), which includes a participatory interactive program showing historical production methods. Furthermore, over the last decade other private museums were established in the city, which may be divided into the following categories: immersion museums showing historical food production with an opportunity to purchase the end products ('Kolomenskaya pastila', 'Kalachnaya', Shvedov's museum and confectionery, etc.); mono-thematic museums (Kolomenskiy Gramophone Museum, Tram Museum, Museum of Favorite Toys, etc.); creative spaces and services ('Artkommunalka. Erofeev i drugie' Art-Residence, Lazhechnikov Literary Café, Museum-Navigator private tourist center, 'Patefonka' loft). The growth in the number of private museums has led not only to the increase of tourist inflow and, consequently, to the development of tourist infrastructure, but also to the transformation of the city center from a partially degraded residential area into a mixed use cultural and residential quarter which attracts new businesses, residents and tenants. Of course, the downside of the process was the rising cost of real estate in the city center; however, it is still not pronounced enough to cause marginalization and out-flow of lower-income population groups.

In parallel with the private initiatives taking place in the city, the attention and resources of the local authorities began to shift more intensively to the historical center of Kolomna. A number of official planning and policy documents have been developed and adopted to comprehensively deal with the new function of the historical city quarters and to manage the increasing inflow of tourists and local residents. The initiatives of the local authorities include reconstruction of streets to make them fully pedestrian (the first was Lazhechnikov street, which is occupied by different kinds of tourist infrastructure and services), as well as minor improvements to the cityscape in line with the Priority Project 'Formation of a comfortable urban environment' - road paving, lighting, play and sport grounds, landscaping in various courtyards of the city.

Summing up, the change in Kolomna's development that began at the end of the 2000 s is an example of measures launched without coordination, which include both topdown and bottom-up elements that mutually influence each other. However, the bottom-up element prevails. The main leader of this process is the community of creative entrepreneurs that formed here over the last decade. They seem to be the most aware of the value of cultural heritage and the need for careful work with it. In this respect they have taken on the function of an informal 'city council', concerned with the development of the historical quarters and creating a norm for work with elements of the cityscape. The role of the regional and local authorities remains minor, and the local community and voluntary sector seem to be (self)excluded from the regeneration agenda. Partnership has been established, but only within the community of entrepreneurs; moreover, it is unclear what type of partnership it is, as it has features of both synergy and transformational models.

\section{Two paths of regeneration - similarities and differences between Poland and Russia}

The medium-sized cities under study are similar in terms of the process that is taking place (Tab. 2).. The focus is on the city center and the activities carried out are changing it to a more vibrant, and creative area, albeit with some signs of gentrification due to interventions of private capital. In both cases, state authorities have provided some tools for 
Table 2. Actors of regeneration in Kolomna and Kalisz

\begin{tabular}{|c|c|c|}
\hline Key actors & Kolomna & Kalisz \\
\hline $\begin{array}{l}\text { State authori- } \\
\text { ties }\end{array}$ & $\begin{array}{l}\text { Provide a general framework for regional and } \\
\text { local development. Partially subsidize local } \\
\text { programs. } \\
\text { Do not provide guidelines or funding explicitly for } \\
\text { urban regeneration. }\end{array}$ & $\begin{array}{l}\text { Provide a framework for local regeneration: } \\
\text { legal regulations, national programs. Partially } \\
\text { subsidize local programs (using EU funds). } \\
\text { Responsible for the implementation of the na- } \\
\text { tional program 'Package for medium-sized cities'. }\end{array}$ \\
\hline $\begin{array}{l}\text { Local/regional } \\
\text { authorities }\end{array}$ & $\begin{array}{l}\text { 'Localize' national programs and projects } \\
\text { (e.g. 'Formation of a comfortable urban } \\
\text { environment'). } \\
\text { Propose some initiatives aimed at urban } \\
\text { regeneration. }\end{array}$ & $\begin{array}{l}\text { Regeneration Office plays a dominant role, i.e. } \\
\text { is responsible for initiating regeneration, prepar- } \\
\text { ing, and implementing a regeneration program. }\end{array}$ \\
\hline Entrepreneurs & $\begin{array}{l}\text { Play a major role in urban regeneration - private } \\
\text { museums, cultural festivals, emergence of tourist } \\
\text { infrastructure (hotels, cafes). Subsequent } \\
\text { transformation of the urban environment. }\end{array}$ & $\begin{array}{l}\text { Play a supplementary role in regeneration. } \\
\text { Involved in commercial investments addressed } \\
\text { at wealthier residents. }\end{array}$ \\
\hline $\begin{array}{l}\text { NGO repre- } \\
\text { sentatives }\end{array}$ & Not involved in urban regeneration & $\begin{array}{l}\text { Play a supplementary role in regeneration. Local } \\
\text { leaders are still lacking. }\end{array}$ \\
\hline Other actors & No data & $\begin{array}{l}\text { Other actors, such as property owners, neigh- } \\
\text { bourhood councils, and residents clustered } \\
\text { around the Regeneration Committee. }\end{array}$ \\
\hline
\end{tabular}

regeneration: the national Priority Project 'Formation of a comfortable urban environment' (in Russia), and the Regeneration Act, National Regeneration Plan, and national program 'Package for medium-sized cities' (in Poland). However, the final shape of the changes was determined by other actors, who are different in Kalisz and in Kolomna. In Kolomna, the first step towards regeneration was taken by the regional and local authorities; however, it was entrepreneurs who developed the city's potential through private investment. In Kalisz, regeneration began and is fostered primarily through the actions of local authorities who adopted the Regeneration Program (Tab. 2).

\section{Summary}

The objective of this paper was to empirically explore the main actors (leaders), both public and private, involved in the current transformation of medium-sized cities in Russia and Poland. First we discussed urban change using the framework of regeneration at the national level, and then analyzed the experiences of two medium-sized cities - Kolomna (Russia) and Kalisz (Poland). The starting point was similar in both countries. During state socialism, urban regeneration was not on the agenda of urban development and planning, except for large-scale demonstrative interventions. Only after the collapse of the system did the need for enhanced livability in cities in general and in their most degraded parts in particular enter the agenda in CEE countries (Scott \& Kuhn, 2012). In subsequent years, however, urban transformations in Poland and Russia headed in different directions. The following common features of regeneration can be indicated. First, the central government provides only some basic tools and framework for regeneration, but it is the activities carried out on a local scale that define and support regeneration. Therefore, in both Russia and Poland urban regeneration is dependent on the local leadership, including political leadership. Second, regeneration activities focus primarily on city centers, which become the showcase of new urban development. In this respect the processes which take place may reinforce the existing intraurban spatial polarization and with a significant share of private capital involved, they may balance 
on the brink of gentrification with the related negative societal effects.

The differences between the regeneration of medium-sized cities in Poland and in Russia seem to be more profound than the similarities. In Poland, regeneration is systematized and institutionalized at the national level through the adoption of the Regeneration Act and specially delegated EU funds. Regeneration is becoming a key issue for local authorities, who try to engage various actors, including entrepreneurs, NGOs, and local communities. In Russia, on the contrary, urban regeneration remains an ad hoc process based on private investment, and thus is very vulnerable to changes in political, economic, and social settings. National, regional, and local authorities focus only on the most pressing issues or provide highly visible, but insubstantial oneoff improvements that do not require much funding and have immediate political benefits (Zupan \& Gunko, 2020).

The differing types of leadership in regeneration in the analyzed countries define the patterns and stability of regeneration. In Poland, despite attempts to use the partnership model, local authorities still play a key role in regeneration, being obliged to act by legal regulations and supported by national and EU funds. In Russia, a partnership is formed among entrepreneurs: they act both like innovative entrepreneurs who seek opportunities to create additional value and local leaders who are preoccupied with local interests (Sotarauta, Beer, \& Gibney, 2017; Grillitsch \& Sotarauta, 2018). In a sense, urban regeneration in Russian medium-sized cities is more 'creative' and free-flowing compared to that in Poland, but it also has no stable external sources of financing and can collapse as suddenly as it began.
The recent debates in comparative urban studies which gained new momentum from the postcolonial critique of urban theory state the need to think beyond the traditional North-South and East-West, as well as the large-small city divides in order to develop more holistic, cosmopolitan, and inclusive conceptualizations of urban change (Robinson, 2006; 2017; Roy, 2009). Since urban regeneration is not self-evident or neutral, more comparative empirical investigations from various cultural contexts are needed to inform and shape our understanding. In this respect our contribution is yet another component bolstering a still fuzzy concept with evidence from an underrepresented part of the world and city type. The two researched cases demonstrate the divergent paths of urban transformations taking place in CEE and likewise prove that urban regeneration is a widely experienced but little understood phenomenon (...) There is no single prescribed form of urban regeneration practice' (Roberts \& Sykes, 2000: 3).

\section{Acknowledgements}

Maria Gunko's research on urban regeneration in Russia was supported by the Basic Research Program of the Institute of Geography Russian Academy of Sciences ("Problems and prospects of Russia's territorial development under conditions of its unevenness and global instability"; AAAAA19-119022190170-1 / 0148-2019-0008).

\section{Editors' note:}

Unless otherwise stated, the sources of tables are the authors', on the basis of their own research.

\section{References}

Alexandrescu, F., Martinat, S., Klusácek, P., Bartke, S. (2014). The path from passivity toward entrepreneurship: Public sector actors in brownfield regeneration processes in Central and Eastern Europe. Organization \& Environment, 27(2), 181-201. https://doi.org/10.4324/9781315392387 
Atkinson, R., Servillo, L., Hamdouch, A.-I. (2017). Small and medium-sized town in Europe: Conceptual, methodological and policy issues. Tijdschrift voor Economische en Sociale Geografie, 108 (4), 365-379. https://doi.org/10.1111/tesg.12252

Badyna, A., Golubchikov, O. (2005). Gentrification in central Moscow - a market process or a deliberate policy? Money, power and people in housing regeneration in Ostozhenka. Geografska Annaler B, 87(2), 113-129. https://doi.org/10.1111/j.0435-3684.2005.00186.x

Beer, A. (2014). Leadership and the governance of rural communities. Journal of Rural Studies, 34, 254-262.

Beer, A., Ayres, S., Clower, T., Faller, F., Sancino, A., Sotarauta, M. (2019). Place leadership and regional economic development: a framework for cross-regional analysis. Regional Studies, 53(2), 171-182. https://doi.org/10.1080/00343404.2018.1447662

Bentley, G., Pugalis, L., Shutt, J. (2017). Leadership and systems of governance: The constraints on the scope for leadership of place-based development in sub-national territories. Regional Studies, 51(2), 194-209. https://doi.org/10.1080/00343404.2016.1181261

Cambridge Dictionary. [13 November 2019] Retrieved from https://dictionary.cambridge.org/dictionary/english/re

Carley, M. (2000). Urban partnerships, governance and the regeneration of Britain's cities. International Planning Studies, 5(3), 273-297. https://doi.org/10.1080/713672858

Carter, A. (2000). Strategy and partnership in urban regeneration. In P. Roberts, H. Sykes, (Eds.) Urban regeneration. A handbook (pp. 37-58). London: Sage. https://doi.org/10.4135/9781446219980.n3

Carter, D. (Ed.) (2016). Remaking post-industrial cities: Lessons from North America and Europe. New YorkLondon: Routledge. https://doi.org/10.4324/9781315707990

CEC (2011). Cities of tomorrow. challenges, visions, ways forward. Brussels: Commission of the European Communities.

Cheshire, P., Hay, D., Carbonaro, G., Bevan, N. (1988). Urban problems and regional policy in the European Community. Report for Commission of the European Communities. European Union: Luxembourg.

Ciesiółka, P. (2018). Urban regeneration as a new trend in the development policy in Poland. Quaestiones Geographicae, 37(2), 109-123. https://doi.org/10.2478/quageo-2018-0015

Collinge, C., Gibney, J., Mabey, C. (2010). Introduction: Leadership and place. In C. Collinge, J. Gibney, C. Mabey (Eds.), Leadership and place (pp. 1-12). Abingdon: Routledge.

Couch, C., Sykes, O., Börstinghaus, W. (2011). Thirty years of urban regeneration in Britain, Germany and France: The importance of context and path dependency. Progress in Planning, 75, 1-52. https://doi.org/10.1016/j.progress.2010.12.001

Dalla Longa, R. (Ed.) (2011). Urban models and public-private partnership. Berlin: Springer-Verlag. https://doi.org/10.1007/978-3-540-70508-6

Doğan, E. (Ed.) (2019). Reinventing Eastern Europe: Imaginaries, identities and transformations. London: Transnational Press.

Doucet, B. (Ed.) (2017). Why Detroit matters. Decline, renewal, and hope in a divided city. Bristol: Policy Press. https://doi.org/10.1332/policypress/9781447327868.001.0001

ESPON (2014). Town: Small and medium sized towns in their functional territorial context: Applied research 2013/1/23: Final Report version 6 November 2014. Luxembourg: ESPON.

European Union (1994). Europe 2000+. Coopération Pour L'aménagement du Territoire européen. European Union: Luxembourg. Retrieved from http://documents.irevues.inist.fr/handle/2042/30248

Feldman, M. (2000). Gentrification and social stratification in Tallinn: Strategies for local governance. SOCO Project Paper, 86, Vienna: Institut für die Wissenschaften vom Menschen.

Földi,Z. (2006). Neighbourhood dynamics in inner-Budapest: A realist approach. Netherlands Geographical Studies, 350, Utrecht: University of Utrecht. 
Frantal, B., Kunc, J., Novakova, E., Klusaček, P., Martinat, S., Osman, R. (2013). Location matters! Exploring brownfields regeneration in a spatial context (A case study of the South Moravian Region, Czech Republic). Moravian Geographical Reports, 21(2), 5-19. https://doi.org/10.2478/mgr-2013-0007

Gorzelak, G. (Ed.) (2019). Social and economic development in Central and Eastern Europe: Stability and change after 1990. London: Routledge. https://doi.org/10.4324/9780429450969

Gómez, L.A.E., González, J.A.G., Navarro, J.M.M. (2019). Medium-sized cities in Spain and their urban areas within national network. Urban Science, 3(1), 5. https://doi.org/10.3390/urbansci3010005

Granger, R. (2010). What now for urban regeneration? Proceedings of the ICE - Urban Design and Planning, 163(1), 9-16. https://doi.org/10.1680/udap.2010.163.1.9

Granger, R. (2016). Social and community issues. In P. Roberts, H. Sykes, R. Granger (Eds.), Urban regeneration (pp. 99-112), London: Sage. https://doi.org/10.4135/9781473921788.n6

Grillitsch, M., Sotarauta, M. (2018). Regional growth paths: From structure to agency and back. Papers in Innovation Studies 2018/1, Lund University, CIRCLE - Center for Innovation, Research and Competences in the Learning Economy. Retrieved from: https://ideas.repec.org/p/hhs/lucirc/2018_001.html

Gunko, M., Pivovar, G. (2018). Uchastie / ne uchastie naseleniya v gorodskom planirovanii [Citizen participation / non-participation in urban planning]. Region: Ekonomika i Sotsiologiya, 2, 241-263.

Gustavsson, E., Elander, I. (2015). Sustainability potential of a redevelopment initiative in Swedish public housing: The ambiguous role of residents' participation and place identity. Progress in Planning, 103, 1-15. https://doi.org/10.1016/j.progress.2014.10.003

Hall, T. (2006). Urban geography (3rd edition). London: Routledge.

Hamdouch, A., Nyseth, T., Demazière, C., Førde, A., Serrano, J., Aarsæther, N. (Eds.) (2016). Creative approaches to planning and local development. Insight form small and medium-sized towns in Europe. London - New York: Routledge. https://doi.org/10.4324/9781315574653

Henderson, V. (1997). Medium size cities. Regional science and urban economics, 27(6), 583-612. https://doi.org/10.1016/s0166-0462(96)02169-2

Inizan, G., Coudroy de Lille, L. (2019). The last of the Soviets' Home: Urban demolition in Moscow. Geographia Polonica, 92(1), 37-56. https://doi.org/10.7163/gpol.0135

Jarczewski, W., Kułaczkowska, A. (Eds.), (2019). Raport o stanie polskich miast. Rewitalizacja. [Report on the state of Polish cities. Revitalization], Warsaw - Kraków: Institute of Urban and Regional Development.

Johnson, R.B., Onwuegbuzie, A.J. (2004). Mixed methods research: A research paradigm whose time has come. Educational researcher, 33(7), 14-26. https://doi.org/10.3102/0013189×033007014

Kaczmarek, S. (2019). Ruining, demolition and regeneration in urban space: Sketching the research problem. Geographia Polonica, 92(1), 5-16. https://doi.org/10.7163/gpol.0133

Kaczmarek, S., Marcińczak, S. (2013). The blessing in disguise. Urban regeneration in Poland in a neoliberal milieu. In M.E. Leary, J. McCarthy (Eds.), The Routledge companion to urban regeneration (pp. 98-106), London: Routledge. https://doi.org/10.4324/9780203108581.ch8

Kinossian, N. (2019). Agents of change in peripheral regions. Baltic Worlds, 12(2), 61-66.

Krzysztofik, R., Kantor-Pietraga, I., Spórna, T. (2013). A dynamic approach to the typology of functional derelict areas (Sosnowiec, Poland). Moravian Geographical Reports, 21(2), 20-35. https://doi.org/10.2478/mgr-2013-0008

Kunzmann, K.R. (2010). Medium-sized towns, strategic planning and creative governance. In Cerreta, M., Concilio, G., Monno, V., (Eds.), Making strategies in spatial planning. Urban and landscape perspectives. (pp. 27-45), Dordrecht: Springer.

Lang, T., Henn, S., Sgibnev, W., Ehrlich, K. (Eds.). (2015). Understanding geographies of polarization and peripheralization. Perspectives from Central and Eastern Europe and beyond. Houndmills, Basingstoke: Palgrave Macmillan. https://doi.org/10.1111/1468-2427.12398 
Lappo, G.M. (1997). Geografiya gorodov [Urban geography]. Moscow: Vlados.

Lees, L., Slater, T., Wyley, E. (2008). Gentrification. London: Routledge.

Lichfield, D. (1992). Urban regeneration for the 1990's. London: London Planning Advisory Committee.

Lux, G., Horvath, G. (2018). The Routledge handbook to regional development in Central and Eastern Europe. London: Routledge. https://doi.org/10.4324/9781315586137

Mackintosh, M. (1992). Partnership: issues of policy and negotiation. Local Economy, 3(7), 210-224. https://doi.org/10.1080/02690949208726149

Ministry for Construction, Housing, and Communal Services of the Russian Federation (2017). Prioritetny proekt 'Formirovanie komfortnoy gorodskoy sredy' [Priority project 'Formation of a comfortable urban environment']. Retrieved from http://www.minstroyrf.ru/trades/gorodskaya-sreda/strategicheskoe-napravlenie-razvitiya-zhkkh-i-gorodskaya-sreda/

Ministry for Economic Development of the Russian Federation (2016). Pasport prioritetnogo proekta 'Kompleksnoe razvities monogorodov' [Passport of the priority project 'Integrated development of singleindustry towns']. Retrieved from http://government.ru/news/25595/

Roberts, P. (2016). The evolution, definition, and purpose of urban regeneration. In P. Roberts, H. Sykes, R. Granger (Eds.), Urban regeneration. (pp. 9-43). London: Sage. https://doi.org/10.4135/9781473921788.n2

Roberts, P., Sykes, H., (Eds.). (2000). Urban regeneration. A handbook. London: Sage.

Roberts, P., Sykes, H., Granger, R., (Eds.). (2017). Urban regeneration. London: Sage. https://doi.org/10.4135/9781473921788

Robinson, J. (2006). Ordinary cities: between modernity and development. London: Routledge.

Robinson, J. (2016). Starting from anywhere, making connections: globalizing urban theory. Eurasian Geography and Economics, 57(4-5), 643-657. https://doi.org/10.1080/15387216.2016.1271617

Rodriguez-Pose, A. (2013). Do institutions matter for regional development? Regional Studies, 47(7), 10341047. https://doi.org/10.1080/00343404.2012.748978

Rosstat. Russian Federal State Statistics Service website. Retrieved from http://www.gks.ru/

Roy, A. (2009). Strangely familiar: Planning and the worlds of insurgence and informality. Planning Theory, 8(1), 7-11. https://doi.org/10.1177/1473095208099294

Ryan, B. (2012). Design after decline. How America rebuilds shrinking cities. Philadelphia: University of Pennsylvania Press. https://doi.org/10.9783/9780812206586

Scott, J.W., Kühn, M. (2012). Urban change and urban development strategies in Central East Europe: A selective assessment of events since 1989. European Planning Studies, 20(7), 1093-1109. https://doi.org/10.1080/09654313.2012.674345

Seawright, J., Gerring, J. (2008). Case selection techniques in case study research. A menu of qualitative and quantitative options. Political Research Quarterly, 61(2), 294-308.

https://doi.org/10.1177/1065912907313077

Set of Rules (2011). SP 42.13330.2011. Gradostroitel'stvo. Planirovka i zastrojka gorodskih i sel'skih poselenij [Urban development. Urban and rural planning and development]. Retrieved from http://docs.cntd.ru/document/1200084712

Sotarauta, M., Beer, A., Gibney, J. (2017). Making sense of leadership in urban and regional development. Regional Studies, 51(2), 187-193. https://doi.org/10.1080/00343404.2016.1267340

Statistical data on revitalization at the level of gminas. Statistics Poland. Retrieved from http://www.stat.gov.pl/ [25 November 2019].

Statistics Poland (GUS). [12 November 2019] Retrieved from http://www.stat.gov.pl/

Stohr, W. (1989). Regional policy at the crossroads: An overview. In L. Albrechts, F. Moulaert, P. Roberts (Eds.), Regional policy at the crossroads: European perspective (pp. 191-197), London: Jessica Kingsley.

Stryjakiewicz T., Kudłak R., Ciesiółka P., Kołsut B., Motek P. (2018) Urban regeneration in Poland's non-core regions. European Planning Studies, 26:2, 316-341, https://doi.org/10.1080/09654313.2017.1361603 
Sykora, L. (2005) Gentrification in post-communist cities. In: R. Atkinson, G. Bridge (Eds.), Gentrification in a global context. The new urban colonialism (pp. 90-105), New York - London: Routledge. https://doi.org/10.4324/9780203392089_chapter_6

Śleszyński, P. (2017). Wyznaczenie i typologia miast średnich tracacych funkcje społeczno-gospodarcze. Przeglad Geograficzny, 89(4), 565-593. https://doi.org/10.7163/przg.2017.4.3

TASS, (2013). K situatsii $v$ gorode Pikalyovo. Dossie [The situation in the city of Pikalevo. A dossier]. 23 December 2013. Retrieved from https://tass.ru/info/853402

Temelová, J. (2009). Urban revitalization in central and inner parts of (post-socialist) cities: Conditions and consequences, In T. Ilmavirta (Ed.), Regenerating urban core (pp. 12-25). Publications in the Center for Urban and Regional Studies, C72.

Van Agtmael, A., Bakker, F. (2016). The smartest places on earth. Why rustbelts are the emerging hotspots of global innovation. New York: Public Affairs.

Watcher, S., Zeuli, K. (2014). Revitalizing American cities. Philadelphia: University of Pennsylvania Press. https://doi.org/10.9783/9780812208887

Zupan, D., Gunko, M. (2020). Researching centre-periphery relations in Russia through the circulation of urban planning and design ideas. The case of the "comfortable city". Gorodskie issledovaniya i praktiki, forthcoming 